\title{
Genetic Variations of miRNAs and the Risk of Oral Squamous Cell Carcinoma: A Case-control Study
}

\section{Oral Skuamoz Hücre Kanseri Riski ve miRNA'ların Genetik Varyasyonları: Olgu- kontrol Çalışması}

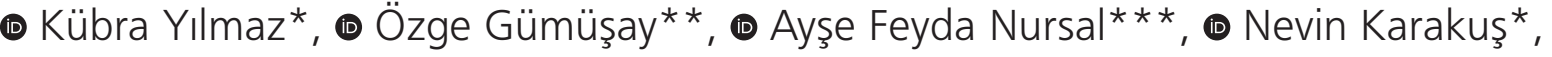 \\ (1) Serbülent Yiğit****** \\ *Gaziosmanpaşa University, Faculty of Medicine, Department of Medical Biology, Tokat, Turkey \\ **Gaziosmanpaşa University, Faculty of Medicine, Department of Medical Oncology, Tokat, Turkey \\ ***Hitit University, Faculty of Medicine, Department of Medical Genetics, Çorum, Turkey \\ $* * * *$ Ondokuz Mayıs University, Faculty of Veterinary, Department of Genetics, Samsun, Turkey
}

\section{Abstract}

Aim: In this study, we investigated the association between two miRNA variants and the risk of oral squamous cell carcinoma (OSCC), and explored the interaction between clinical factors in the Turkish population.

Methods: In this case control study, a total of 142 subjects were genotyped by polymerase chain reaction-restriction fragment length polymorphism to analyze miR-146aG/C (rs2910164) and miR-149C/T (rs2292832) variants. Associations between OSCC risk and clinicopathological characteristics were analyzed by chisquare test

Results: There was a significant difference in genotype and allele frequencies of $m i R-146 a G / C$ variant between patients and control individuals. miR-146aG/C CC genotype and C allele were higher in the patient group compared to the control group $(p=0.000, p=0.0001$, respectively). Significant differences were also observed when the patients and the controls were compared according to $C C$ vs $G G+G C(p=0.0002)$ and $G G$ vs $G C+C C$ $(p=0.002)$. In combined analysis, CC-CT combined genotype increased in patient group compared to controls $(p=0.002)$, while GC-CT combined genotype increased in controls compared to patients $(p=0.028)$,

Conclusion: Our study provides evidence that miR-146aG/C variant may play an important role in susceptibility to OSCC in the Turkish population.

Keywords: Oral squamous cell carcinoma, microRNA, variant
Amaç: Bu çalışmada, iki miRNA varyantı ve oral skuamoz hücreli kanser (OSHK) riski arasındaki ilişkiyi inceledik ve Türk popülasyonundaki klinik faktörlerle arasındaki etkileşimi araştırdık.

Yöntemler: $\mathrm{Bu}$ olgu-kontrol çalışmasında, miR-146aG/C (rs2910164) ve miR-149C/T (rs2292832) varyantlarını analiz etmek için toplam 142 kişi polimeraz zincir reaksiyonu- sınırlayıcı enzim parça uzunluk polimorfizmi ile genotiplendi. OSHK ve klinikopatolojik özelliklerin ilişkisi $\chi^{2}$ testi ile analiz edildi.

Bulgular: Hastalar ve kontrol bireyleri arasında miR-146aG/C varyant genotip ve alel sıklıklarında önemli fark vardı. miR$146 a$ G/C CC genotipi ve C aleli hasta grubunda kontrol grubuna göre daha yüksekti ( $p=0,000, p=0,0001$, sırasıly). Hastalar ve kontroller kıyaslandığında CC'ye göre $G G+G C(p=0,0002)$ ve $G G^{\prime}$ ye göre $G C+C C(p=0,002)$ önemli farklar saptandı. Kombine analizde, GC/CT kombine genotipi kontrollerde hastalara göre artmışken ( $p=0,0028)$, CC-CT kombine genotipi hasta grubunda kontrollere göre artmıştı $(p=0,002)$.

Sonuç: Çalışmamı miR-146aG/C varyantının Türk popülasyonunda OSHK'ye yatkınlıkta önemli rol oynayabileceği kanıtlarını göstermektedir.

Anahtar Sözcükler: Oral skuamoz hücreli kanser, mikroRNA, varyant
Address for Correspondence/Yazışma Adresi: Ayşe Feyda Nursal, Hitit University, Faculty of Medicine, Department of Medical Genetics, Çorum, Turkey E-mail: feyda.nursal@gmail.com ORCID: orcid.org/0000-0001-7639-1122

Received/Geliş Tarihi: 07 February 2020 Accepted/Kabul Tarihi: 24 March 2020
${ }^{\circ}$ Copyright 2020 by The Medical Bulletin of istanbul Haseki Training and Research Hospital The Medical Bulletin of Haseki published by Galenos Yayınevi.

${ }^{8}$ Telif Hakkı 2020 istanbul Haseki Eğitim ve Araştırma Hastanesi Haseki Tıp Bülteni, Galenos Yayınevi tarafindan yayılanmıştır. 


\section{Introduction}

Oral squamous cell carcinoma (OSCC) is the most prevalent oral malignancy, accounting for up to $80-90 \%$ of all malignant neoplasms of the oral cavity (1). Tobacco use (chewing with or without smoking), alcohol consumption, and human papilloma virus (HPV) infection are among the major risk factors for OSCC, yet, molecular mechanisms involved in OSCC are still unclear, whilst genetic tendency has been studied extensively (2). Recognition of biomarkers for screening high-risk status for increased tendency to cancer is crucial for prevention of this malignancy.

MicroRNAs (miRNAs) are small (ranging often between 18 to 25 nucleotide in size), single stranded, and noncoding RNAs. Particularly, miRNAs can modulate gene expression at the post-transcriptional level by repressing translation of protein coding genes, or cleaving target mRNAs, based on the level of complementarity between the miRNA and its target mRNA (3). These small miRNAs are involved in a numerous physiologic and pathological events including cell cycle, differentiation, growth, and metabolism along with myriad diseases like cancer (3). Studies have reported that microRNAs may be critical elements in oncogenesis, acting as tumor suppressors and/or oncogenes, and influence the etiology of several cancer types (4). Single nucleotide polymorphisms (SNPs) found in miRNA encoding gene (miR-SNPs) have attracted attention due to their potent involvement in cancer. It is already known that miR-SNPs can affect the transcription of the target gene, modify the processing of pri-miRNA or pre-miRNA and have impact on interaction between miRNA and mRNA (5). Studies have shown that miR146aG/C (rs2910164), and miR-149C/T (rs2292832) SNPs play a major role in carcinogenesis owing to their targeting on various vital genes and are involved in diverse types of cancers (6).

Therefore, we performed a study to investigate the association between two common miRNA polymorphisms and the risk of OSCC in a Turkish population.

\section{Methods}

\section{Study Population}

A cohort of 142 individuals, including 42 patients with OSCC and 100 healthy controls was enrolled in this case control study. Patients were treated at the Department of Medical Oncology, Training and Research Hospital, Gaziosmanpaşa University, Tokat, Turkey. The diagnosis of OSCC was based on pathological features of tissue specimens. Clinical information, including age, gender, smoking, alcohol consumption and tumor-nodemetastasis stages, were obtained from patient's medical charts. 100 age- and sex-matched healthy individuals, who did not have any evidence of OSCC or any other overt oral diseases, constituted the control group. Informed written consent was obtained from all subjects. This study protocol was approved by the Local Ethics Committee (Gaziosmanpasa University, Medical Faculty, decision no: 17-KAEK-061), in accordance with the ethical standards for human experimentation established by the Declaration of Helsinki.

\section{Genotyping}

$2 \mathrm{~mL}$ of venous blood was obtained from each participant (OSCC patients and healthy controls) and DNA was extracted from all the samples using a commercial kit (Sigma-Aldrich, Taufkirchen, Germany) according to the manufacturer's instructions. Using genomic DNA, miRNAs variants were identified by polymerase chain reactionrestriction fragment length polymorphism (PCR-RFLP) methods as previously described $(7,8)$.

\section{Statistical Analysis}

Statistical analysis was performed using the Statistical Package for the Social Sciences (IBM SPSS Statistics, version 20) and OpenEpi software package version 3.01 (www.openepi.com). The sample size was assessed using the Power and Sample size Calculation software. The relationships between variants and the clinical characteristics of patients were analyzed by using the chisquare test or analysis of variance (ANOVA) statistics. Chisquare test and Fisher's exact test were used to compare categorical variables appropriately. Odds ratio (OR) and 95\% confidence interval $(\mathrm{Cl})$ were used for the assessment of risk factors. All $p$ values were 2 -tailed and $p$ values less than 0.05 were considered statistically significant.

\section{Results}

A total of 42 OSCC patients and 100 age and gender matched healthy controls were genotyped for miR 146aG/C and miR-149C/T variants. Demographic characteristics of the study participants are shown in Table 1.The distribution of $m i R ~ 146 a \mathrm{G} / \mathrm{C}$ and $\mathrm{miR}-149 \mathrm{C} / \mathrm{T}$ variants genotypes and allele frequencies in the study and control groups are shown in Table 2.

\section{$\operatorname{miR} 146 a G / C$}

The frequency of GG, GC, and CC genotype was $31.0 \%$ vs $45.2 \%, 23.8 \%$ vs $59 \%$, and $40 \%$ vs $1 \%$ in OSCC patients and control individuals, respectively. There was a statistically significant difference in genotype and allele frequencies of $\mathrm{miR} 146 \mathrm{aG} / \mathrm{C}$ variant between the patients and the control subjects. miR-146G/C CC genotype and $C$ allele were found to be increased in the patient group compared to the control group $(p=0.000$ and $p=0.0001$, respectively). Statistically significant differences were also observed when the patients and the controls were compared according to CC vs GG+GC ( $p=0.0002$, OR: 
30.9, $\mathrm{Cl}: 95 \%$ : $3.81-251.1)$ and $\mathrm{GG}$ vs $\mathrm{GC}+\mathrm{CC}(\mathrm{p}=0.002$, OR: 3.21, Cl: 95\%: 1.49-6.90).

\section{miR $149 \mathrm{C} / \mathrm{T}$}

The frequency of the $\mathrm{CC}, \mathrm{CT}$, and TT genotypes of the miR-149C/T variant in the patients was $28.6 \%, 59.5 \%$, and $11.9 \%$ respectively; and in the controls, the frequency was $40 \%, 51 \%$, and $9 \%$, respectively. The genotype and allele distribution of miR-149C/T variant did not show any statistically significant difference between the patients and the controls ( $p=0.425$ and $p=0.253$, respectively).

Furthermore, we also analyzed whether any differences existed in the clinical and demographic characteristics of patients according to distributions of miR-146aG/C and miR-149C/T genotypes (Table 3). There was no significant difference between the variants and the clinical characteristics $(p>0.05)$. The associations between miR-146aG/C/miR-149C/T and the combined genotypes with OSCC susceptibility were further evaluated by

\begin{tabular}{|l|l|l|l|}
\hline \multicolumn{3}{|l|}{ Table 1. The demographical characteristics of the study subjects } \\
\hline \multicolumn{2}{|c|}{} & $\begin{array}{l}\text { Patient group } \\
(\mathbf{n = 4 2})(\%)\end{array}$ & $\begin{array}{l}\text { Control group } \\
(\mathbf{n}=100)(\%)\end{array}$ \\
\hline \multirow{2}{*}{ Age } & $63.05 \pm 13.250$ & $60.37 \pm 8.666$ \\
\hline \multirow{2}{*}{ Gender } & Female & $15(35.7)$ & $34(34)$ \\
\cline { 3 - 4 } & Male & $27(64.3)$ & $66(63.3)$ \\
\hline
\end{tabular}

stratification analysis for OSCC patients (Table 4). In combined analysis, CC-CT genotype increased in patient group compared to controls $(p=0.002)$, while $G C / C T$ combined genotype increased in controls compared to patients $(p=0.028)$,

\section{Discussion}

OSCC is an important cause of morbidity and mortality all over the world. Although enormous advances occurred in diagnostic and therapeutic methods, the prognosis of OSCC is still poor, with a 5-year survival rate of nearly $50 \%$ (9). There is considerable evidence supporting that miRNA deregulation plays a fundamental role in carcinogenesis. Distorted expression profiles of miRNAs in several cancer types lead to different malignant phenotypes for tumor progression, and this in turn may promote chemoresistance and eventually result in a poor prognosis (10). Hence, miRNAs have been studied in depth to determine new diagnostic and prognostic cancer biomarkers, and to help development of efficient therapeutic targets. MiRNAs are involved in the pathogenesis of oral cancer and are believed to be potential biomarkers in cancer diagnosis, owing to their aberrant expression and single nucleotide polymorphisms (11). Myriad studies have been performed to establish if miRNAs have an impact on susceptibility to OSCC, and the results have been disputable and discrepant.

\begin{tabular}{|c|c|c|c|c|}
\hline \multicolumn{5}{|c|}{$m i R-146 a G / C$} \\
\hline & Patient group & Control group & $p$ & OR, \% $95 \mathrm{Cl}$ \\
\hline Genotypes & $n=42(\%)$ & $\mathrm{n}=100(\%)$ & & \\
\hline GG & $13(31.0)$ & $59(59.0)$ & \multirow{3}{*}{0.000} & \multirow{3}{*}{ - } \\
\hline GC & $19(45.2)$ & $40(40)$ & & \\
\hline CC & $10(23.8)$ & $1(1)$ & & \\
\hline GG+GC:CC & 32 (76.19):10 (23.81) & $99(99): 1(1)$ & 0.002 & $30.9(3.81-251.1)$ \\
\hline GG:GC+CC & $13(30.95): 29(69.05)$ & $59(59): 41(41)$ & 0.002 & $3.21(1.49-6.90)$ \\
\hline \multicolumn{5}{|l|}{ Alleles } \\
\hline G & $45(53.57)$ & $158(79)$ & \multirow{2}{*}{0.0001} & \multirow{2}{*}{$3.26(1.88-5.64)$} \\
\hline C & $39(46.43)$ & $42(21)$ & & \\
\hline \multicolumn{5}{|l|}{$\operatorname{miR}-149 \mathrm{C} / \mathrm{T}$} \\
\hline & Patient group & Control group & $p$ & OR, \% $95 \mathrm{Cl}$ \\
\hline Genotypes & $n=42(\%)$ & $\mathrm{n}=100(\%)$ & & \\
\hline $\mathrm{CC}$ & $12(28.6)$ & $40(40)$ & \multirow{3}{*}{0.425} & \multirow{3}{*}{ - } \\
\hline CT & $25(59.5)$ & $51(51)$ & & \\
\hline TT & $5(11.9)$ & $9(9)$ & & \\
\hline CC+CT:TT & 37 (88.09) :5 (11.91) & $91(91): 9(9)$ & 0.596 & $1.36(0.42-4.35)$ \\
\hline $\mathrm{CC}: \mathrm{CT}+\mathrm{TT}$ & $12(28.57): 30(71.43)$ & $40(40): 60(60)$ & 0.197 & $1.66(0.76-3.63)$ \\
\hline \multicolumn{5}{|l|}{ Alleles } \\
\hline C & $49(58.33)$ & $131(65.5)$ & \multirow{2}{*}{0.253} & \multirow{2}{*}{$1.35(0.80-2.28)$} \\
\hline$T$ & $35(41.66)$ & 69 (34.5) & & \\
\hline
\end{tabular}




\begin{tabular}{|c|c|c|c|c|c|c|c|c|}
\hline \multirow{3}{*}{$\begin{array}{l}\text { Clinical features } \\
\text { Genotypes }\end{array}$} & \multicolumn{4}{|c|}{ miR-146aG/C } & \multicolumn{3}{|c|}{$m i R-149 C / T$} & \multirow{3}{*}{$p$} \\
\hline & GG & GC & CC & \multirow[t]{2}{*}{$p$} & CC & CT & TT & \\
\hline & n (\%) & $n(\%)$ & $n(\%)$ & & n (\%) & n (\%) & n (\%) & \\
\hline \multicolumn{9}{|l|}{ Alcohol } \\
\hline Yes & $2(25.0)$ & $5(62.5)$ & $1(12.5)$ & \multirow[b]{2}{*}{0.523} & $4(50.0)$ & $4(50.0)$ & $0(0)$ & \multirow[b]{2}{*}{0.233} \\
\hline No & $11(32.4)$ & $14(41.2)$ & $9(26.5)$ & & $8(23.5)$ & $21(61.8)$ & $5(14.7)$ & \\
\hline \multicolumn{9}{|l|}{ Smoking } \\
\hline Yes & $1(20)$ & $3(60.0)$ & $1(20.0)$ & \multirow{2}{*}{0.861} & $3(60.0)$ & $2(40.0)$ & $0(0)$ & \multirow[b]{2}{*}{0.342} \\
\hline No & $10(33.3)$ & $12(40.0)$ & $8(26.7)$ & & $7(23.3)$ & $18(60.0)$ & $5(16.7)$ & \\
\hline \multicolumn{9}{|l|}{ Family history } \\
\hline Yes & $2(28.6)$ & $4(57.1)$ & $1(14.3)$ & \multirow[b]{2}{*}{0.741} & $3(42.9)$ & $4(57.1)$ & $0(0)$ & \multirow[b]{2}{*}{0.448} \\
\hline No & $11(31.4)$ & $15(42.9)$ & $9(25.7)$ & & $9(25.7)$ & $21(60.0)$ & $5(14.3)$ & \\
\hline \multicolumn{9}{|c|}{ Treatment response } \\
\hline Yes & $9(31.0)$ & $14(48.3)$ & $6(20.7)$ & \multirow[b]{2}{*}{0.606} & $8(27.6)$ & $18(62.1)$ & $3(10.3)$ & \multirow[b]{2}{*}{0.746} \\
\hline No & $4(33.3)$ & $4(33.3)$ & $4(33.3)$ & & $4(33.3)$ & $6(50)$ & $2(16.7)$ & \\
\hline \multicolumn{9}{|l|}{ Living status } \\
\hline Living & $11(31.4)$ & $14(40.0)$ & $10(28.6)$ & \multirow[b]{2}{*}{0.606} & $10(28.6)$ & $22(62.9)$ & $3(8.6)$ & \multirow[b]{2}{*}{0.309} \\
\hline Exitus & $2(28.6)$ & $5(71.4)$ & $0(0)$ & & $2(28.6)$ & $3(42.9)$ & $2(28.6)$ & \\
\hline \multicolumn{9}{|l|}{ Job } \\
\hline Farmer & $4(36.4)$ & $6(54.5)$ & $1(9.1)$ & \multirow{5}{*}{0.316} & $2(18.2)$ & 7 (63.6) & $2(18.2)$ & \multirow{5}{*}{0.641} \\
\hline Housewife & $2(16.7)$ & $4(33.3)$ & $6(50)$ & & $2(16.7)$ & $9(75.0)$ & $1(8.3)$ & \\
\hline Employee & $5(33.3)$ & $7(46.7)$ & $3(20.0)$ & & $6(40.0)$ & 7 (46.7) & $2(13.3)$ & \\
\hline Officer & $2(66.7)$ & $1(33.3)$ & $0(0)$ & & 1 (33.3) & $2(66.7)$ & $0(0)$ & \\
\hline Unemployed & $0(0)$ & $1(100)$ & $0(0)$ & & $1(100)$ & $0(0)$ & $0(0)$ & \\
\hline
\end{tabular}

\begin{tabular}{|c|c|c|c|}
\hline$m i R-146 a G / C-m i R 149 C / T$ & $\begin{array}{l}\text { Patient } \\
\text { group }\end{array}$ & \begin{tabular}{|l} 
Control \\
group
\end{tabular} & $p$ \\
\hline & n (\%) & n (\%) & \\
\hline GG-CC & $5(11.9)$ & $19(19.0)$ & 0.305 \\
\hline GC-CC & $5(11.9)$ & $21(21.0)$ & 0.201 \\
\hline CC-CC & $2(4.8)$ & $0(0)$ & 0.172 \\
\hline GG-CT & $7(16.7)$ & $35(35.0)$ & 0.028 \\
\hline GC-CT & $11(26.2)$ & $16(16.0)$ & 0.158 \\
\hline CC-CT & $7(16.7)$ & $0(0)$ & 0.002 \\
\hline GG-TT & $1(2.4)$ & $5(5.0)$ & 0.851 \\
\hline GC-TT & $3(7.1)$ & $3(3.0)$ & 0.488 \\
\hline CC-TT & $1(2.4)$ & $1(1.0)$ & 0.999 \\
\hline
\end{tabular}

Human miR-146a is located in the LOC285628 gene on human chromosome 5 (12). miR-146a is induced by the toll-like receptor 4 found in the NF-KB-dependent signaling pathway, resulting in the downregulation of IL-1 receptor-associated kinase 1 and TNF receptorassociated factor 6 (13). The miR-146a variant bears a $\mathrm{G} / \mathrm{C}$ nucleotide substitution which cause a modification from $G: U$ pair to $C: U$ mismatch in the stem structure of miR-146a precursor. This variant in miR-146a changed the mature miR-146a expression level that played a role in the regulation of cell differentiation and cancer development (14). Wang et al. (15) conducted a metaanalysis and reported that miR-146aG/C variant enhanced the risk of cancer in dominant model when all studies were considered in the meta-analysis. Stratified analysis showed a significant link between this variant and cancer susceptibility in Asians but not in Caucasian populations. Numerous studies demonstrate the crucial association between miR-146aG/C variant and risk of cancer, such as breast cancer (16), lung cancer (17), bladder cancer (18), and hepatacellular carcinoma (19). Miao et al. (20) and Liu et al. (21) showed that miR-146aG/C did not affect the risk of head and neck cancers. Also, Zhang et al. (22) and Palmieri et al. (23) reported that there was no significant association between $\operatorname{miR}-146 a G / C$ variant and OSCC in Chinese and Italian populations. Another study showed that these variants may modify the risk of HPV16associated OSCC, particularly in never smokers (24). Hung et al. (25) found that miR-146aG/C variant was associated with advanced nodal metastasis of OSCC and higher miR-146 expression in tumors. Chen et al. (26) reported that miR-146aG/C variant $\mathrm{G} / \mathrm{G}$ genotype was associated with decreased risk of OSCC $(p<0.05)$. A meta-analysis of 66 case-control studies found that $\mathrm{miR}-146 \mathrm{aG} / \mathrm{C}$ was 
a risk factor for head and neck squamosus cell carcinoma (HNSCC). This meta-analysis included four studies from a Caucasian population and one study from a Chinese population (27). Also, in stratified analysis, the authors found that the miR-146aG/C C allele or the CC genotype was a risk factor for HNSCC. Niu et al. (28) observed that miR-146aG/C increased significantly head and neck cancer risk in Caucasian population. The reasons for these conflicting results may be different tumour sites, small sample sizes, and lack of information such as other risk factors or confounders. Our study revealed an association between $\mathrm{miR}-146 \mathrm{aG} / \mathrm{C}$ variant and the risk of OSCC in our population. miR-146aG/C CC genotype and C allele were associated with increased risk of OSCC ( $p=0.000$ and $p=0.0001$, respectively) (Table 2). Furthermore, there was a statistically significant difference when the patients and the controls were compared according to $C C$ vs $G G+G C$ and $G G$ vs $G C+C C(p=0.0002$ and $p=0.002$, respectively). These results are compatible with the results of the study by Niu et al. (28)

The single nucleotide polymorphism of miR-149 gene was first identified by $\mathrm{Hu}$ et al. (29) and colleagues. A $C / T$ genetic variant was reported in the miR-149 gene and was located in the stem region adjacent to the mature miR-149C/T sequence. miR-149C/T is a proapoptotic miRNA and it represses the expression of Akt1 and E2F1. Silencing of Akt1 and E2F1 can generate apoptosis in human tumour cell lines (30). Recent studies reported that miR-149C/T can alter the expression of mature miRNAs or the binding activities to target mRNA, and therefore affect cancer risk via several pathways (30). To date, numerous genetic association studies have been conducted to examine the relationship between the $m i R-149 C / T$ and the risk of several cancers, including colorectal cancer (31), and hepatocellular carcinoma (32). Wei et al. (33) found that the CC genotype of miR-149C/T was significantly associated with an increased risk of papillary thyroid cancer compared with TT homozygote. But, Li et al. (34) reported that $m i R-149 C / T$ variant could decrease digestive cancer susceptibility in a meta-analysis study. Tu et al. (35) showed that miR-149 expression was downregulated in HNSCC compared to normal mucosa and this was associated with a poorer patient survival. Additionally, HNSCC patients with the miR-149C/T T/T genotype have more advanced tumours and a worse prognosis. In addition, it was found that the CT and TT genotypes of miR-149C/T variant were significantly associated with OSCC (30). In the present study, there was no evidence of association between miR-149C/T polymorphism and the risk of OSCC.

The association between miRNAs genotypes and clinicopathological parameters of OSCC was also analysed in our study. Genotype distributions of $\mathrm{miR}-146 \mathrm{aG} / \mathrm{C}$ and
miR-149C/T were not related to clinical features ( $p>0.05)$. But there was a statistically significant difference in the combined analysis. We found that GG/CT combined genotype was associated with decreased risk of OSCC $(p=0.028)$ while CC-CT combined genotype was associated with increased risk of OSCC $(p=0.002)$ (Table 4).

\section{Study Limitations}

In this study, several limitations need to be addressed. First, a relatively small sample size may limit the statistical power of our study, especially in the stratification analysis. Second, we selected only OSCC patients as our study population and excluded other head and neck cancer patients in order to control some confounding bias.

\section{Conclusion}

In this case-control study, we examined associations between two common variants in miRNAs (miR-146aG/C and $m i R-149(/ T)$ and OSCC risk. To the best of our knowledge, this is the first study that correlates the genotype and allele frequencies of these variants with OSCC, in a Turkish population. Our results demonstrate that $m i R-146 a \mathrm{G} / \mathrm{C}$ gene may play an important role in the development of OSCC in a Turkish population. But it is necessary to conduct further well-designed studies based on larger sample size and homogeneous cancer patients to validate our findings.

\section{Authorship Contributions}

Concept: S.Y., Ö.G. Design: S.Y., K.Y. Data Collection or Processing: Ö.G., K.Y. Analysis or Interpretation: S.Y., K.Y. Literature Search: A.F.N., N.K. Writing: A.F.N., N.K.

Conflict of Interest: This study was conducted as a master's thesis. The authors confirm that this article's content has no conflicts of interest.

Financial Disclosure: The authors declared that this study received no financial support.

\section{References}

1. Johnson NW, Jayasekara $P$, Amarasinghe AA. Squamous cell carcinoma and precursor lesions of the oral cavity: epidemiology and etiology. Periodontol 2000 2011;57:19-37.

2. Zeng XT, Luo W, Geng PL, GuoY, Niu YM, Leng WD. Association between the TP53 codon 72 polymorphism and risk of oral squamous cell carcinoma in Asians: a meta-analysis. BMC Cancer 2014;14:469.

3. Lu J, Getz G, Miska EA, et al. MicroRNA expression profiles classify human cancers. Nature 2005;435:834-38.

4. Osada H, Takahashi T. MicroRNAs in biological processes and carcinogenesis. Carcinogenesis 2007;28:2-12.

5. Hu Y, Yu CY, Wang JL, Guan J, Chen HY, Fang JY. MicroRNA sequence polymorphisms and the risk of different types of cancer. Sci Rep 2014;4:3648. 
6. Farokhizadeh Z, Dehbidi S, Geramizadeh B, et al. Association of MicroRNA Polymorphisms With Hepatocellular Carcinoma in an Iranian Population. Ann Lab Med 2019;39:58-66.

7. Zeng Y, Sun QM, Liu NN, et al. Correlation between pre-miR146a C/G polymorphism and gastric cancer risk in Chinese population. World J Gastroenterol 2010;16:3578-83.

8. Chayeb V, Mahjoub S, Zitouni $H$, et al. Contribution of microRNA-149, microRNA-146a, and microRNA-196a2 SNPs in colorectal cancer risk and clinicopathological features in Tunisia. Gene 2018;666:100-7.

9. Shah JP, Gil Z. Current concepts in management of oral cancer-surgery. Oral Oncol 2009; 45:394-401.

10. Kawahara K, Nakayama H, Nagata M, et al. A low Dicer expression is associated with resistance to 5-FU-based chemoradiotherapy and a shorter overall survival in patients with oral squamous cell carcinoma. J Oral Pathol Med 2014;43:350-6.

11. Karatas OF, Oner M, Abay A, Diyapoglu A. MicroRNAs in human tongue squamous cell carcinoma: from pathogenesis to therapeutic implications. Oral Oncol 2017;67:124-30.

12. Taganov KD, Boldin MP, Chang KJ, Baltimore D. NF-KBdependent induction of microRNA miRNA-146, an inhibitor targeted to signaling proteins of innate immune responses. Proc Natl Acad Sci USA 2006;103:12481-6.

13. Ma X, Buscaglia LEB, Barker JR, Li Y. MicroRNAs in NF-кB signaling.Journal of Molecular Cell Biolog 2011;3:159-66.

14. Jazdzewski K, Murray EL, Franssila K, Jarzab B, Schoenberg DR, de la Chapelle A. Common SNP in pre-miR-146a decreases mature miR expression and predisposes to papillary thyroid carcinoma. Proc Natl Acad Sci USA 2008;105:7269-74.

15. Wang J, Bi J, Liu X, Li K, Di J, Wang B. Has-miR-146a polymorphism (rs2910164) and cancer risk: a meta-analysis of 19 case-control studies. Mol Biol Rep 2012;39:4571-9.

16. Lian H, Wang L, Zhang J. Increased Risk of Breast Cancer Associated with CC Genotype of Has-miR-146a Rs2910164 Polymorphism in Europeans. PLoS One 2012;7:e31615.

17. Yin Z, Cui Z, Ren Y, Xia L, Li H, Zhou B. MiR-146a polymorphism correlates with lung cancer risk in Chinese nonsmoking females. Oncotarget 2017;8:2275-83.

18. Wang $\mathrm{M}$, Chu H, Li P, et al. Genetic variants in miRNAs predict bladder cancer risk and recurrence. Cancer Res 2012;72:617382.

19. Xu T, Zhu Y, Wei QK, et al. A functional polymorphism in the miR-146a gene is associated with the risk for hepatocellular carcinoma. Carcinogenesis 2008;29:2126-31.

20. Miao L, Wang L, Zhu L, et al. Association of microRNA polymorphisms with the risk of head and neck squamous cell carcinoma in a Chinese population: a case-control study. Chin J Cancer 2016;35:77.

21. Liu Z, Li G, Wei S, et al. Genetic variants in selected premicroRNA genes and the risk of squamous cell carcinoma of the head and neck. Cancer 2010;116:4753-60.

22. Zhang E, Xu Z, Duan W, Huang S, Lu L. Association between polymorphisms in pre-miRNA genes and risk of oral squamous cell cancer in a Chinese population. PLoS One 2017; 12:e0176044.

23. Palmieri A, Carinci F, Martinelli M, et al. Role of the MIR146A polymorphism in the origin and progression of oral squamous cell carcinoma. Eur J Oral Sci 2014;122:198-201.

24. Song $X$, Sturgis EM, Liu J, et al. MicroRNA variants increase the risk of HPV-associated squamous cell carcinoma of the oropharynx in never smokers. PLoS One 2013; 8:e56622.

25. Hung PS, Chang KW, Kao SY, Chu TH, Liu CJ, Lin SC. Association between the rs2910164 polymorphism in pre-mir-146a and oral carcinoma progression. Oral Oncol 2012;48:404-8.

26. Chen HC, Tseng YK, Chi CC, et al. Genetic variants in microRNA-146a (C>G) and microRNA-1269b (G>C) are associated with the decreased risk of oral premalignant lesions, oral cancer, and pharyngeal cancer. Arch Oral Biol 2016;72:21-32.

27. Ma XP, Zhang T, Peng B, Yu L, de Jiang K. Association between microRNA polymorphisms and cancer risk based on the findings of 66 case-control studies. PLoS One 2013;8:e79584.

28. Niu YM, Du XY, Lu MY, Xu QL, Luo J, Shen M. Significant association between functional microRNA polymorphisms and head and neck cancer susceptibility: a comprehensive meta-analysis. Sci Rep 2015;5:12972.

29. Hu Z, Chen J, Tian T, et al. Genetic variants of miRNA sequences and non-small cell lung cancer survival. J Clin Invest 2008;118:2600-8.

30. Sushma PS, Jamil K, Kumar PU, Satyanarayana U, Ramakrishna M, Triveni B. Genetic Variation in MicroRNAs and Risk of Oral Squamous Cell Carcinoma in South Indian Population. Asian Pac J Cancer Prev 2015;16:7589-94.

31. Pan XM, Xiao X, Qin HJ, et al. MicroRNA variants and colorectal cancer risk: a meta-analysis. Genet Mol Res 2016;15.

32. Jia H, Yu H, Liu Q. Single nucleotide polymorphisms of MIR149 gene rs2292832 contributes to the risk of hepatocellular carcinoma, but not overall cancer: a meta-analysis. Minerva medica 2016;107:259-69.

33. Wei WJ, Lu ZW, Li DS, et al. Association of the miR-149 Rs2292832 polymorphism with papillary thyroid cancer risk and clinicopathologic characteristics in a Chinese population. Int J Mol Sci 2014;15: 20968-81.

34. Li L, Liu T, Li Z, Zhang L, Zhang Z. The miR-149 rs2292832 T/C polymorphism may decrease digestive cancer susceptibility: an updated meta-analysis. Int J Clin Exp Med 2015;8:1535161.

35. Tu HF, Liu CJ, Chang CL, et al. The association between genetic polymorphism and the processing efficiency of miR149 affects the prognosis of patients with head and neck squamous cell carcinoma. PLoS One 2012;7:e51606. 